\title{
Sensitivity Analysis of Banana Chips Small Business
}

\author{
Agnes Quartina Pudjiastuti ${ }^{\circledR}$, Nur Ida Iriani ${ }^{2}$, Ana Arifatus Sa'diyah ${ }^{1}$ \\ ${ }^{1}$ Program Studi Agribisnis Universitas Tribhuwana Tungga Dewi \\ ${ }^{2}$ Program Studi Manajemen Universitas Tribhuwana Tungga Dewi
}

DOI: https://doi.org/10.32781/cakrawala.v12i2.280

\begin{tabular}{|c|c|}
\hline ARTICLE INFO & Abstract: \\
\hline $\begin{array}{l}\text { Banana Chips } \\
\text { Feasibility Study } \\
\text { Sensitivity } \\
\text { Total Cost } \\
\text { Production. }\end{array}$ & $\begin{array}{l}\text { Banana chips are one of the traditional foods favored by Indonesian people and are } \\
\text { mostly cultivated on a small scale. This study aims to analyze the feasibility and sensitivity } \\
\text { of banana chips business. Primary data to compile cash flow in } 2017 \text { was obtained from } \\
\text { small business of banana chips which was then analyzed feasibility financially. Sensitivity } \\
\text { analysis was based on the increase in total cost and decreased production. The results of } \\
\text { the analvsis show that existing banana chips business was categorized as feasible based }\end{array}$ \\
\hline Article History: & $\begin{array}{l}\text { on the criteria of gross } B / C \text {, net } B / C, N P V \text { and IRR. The banana chips business was still } \\
\text { feasible even though the total cost increased by } 5 \% \text { and production decreased by } 15 \% \text {. }\end{array}$ \\
\hline Received : November 2018 & \\
\hline Accepted : December 2018 & \\
\hline
\end{tabular}

\section{Introduction}

Banana is one of the agricultural commodities that are very beneficial to human health because of its nutrients (Sonawane et al., 2011), is a staple food in Uganda (Alex et al., 2015), is one of most important food crops in the world (Adeyanju et al., 2016) and functionally according to Oi et al. (2013) it will be optimal benefits, when it is processed for example into banana flour. Bananas can also be made a variety of processed foods, including banana chips. Banana chips is one of traditional foods favored by people in Indonesia. This business has a backward linkage with agri-cultural sector because it uses raw materials from this sector ie bananas. The implication, development of banana chips business will have an impact on development of banana farming due to increasing need of raw materials.
Banana chips business is generally a small-scale business, but has an important role in Indonesian economy. According to Tambunan (2013), small business is a largest part of existing business in Indonesia and contributes significantly to job creation, and poverty reduction.

In Indonesia, small businesses are part of people's economic activities, small-scale and meet criteria of net worth or annual sales and business ownership. According to provisions of the Law of Indonesian Republic, Number 9 on 1995, criteria for small business are: a) having a net worth of IDR 200,000,000, excluding land and building of business premises; or b) having annual sales of not more than IDR $1,000,000,000$; c) belonging to an Indonesian citizen; d) not a subsidiary or branch of a company owned, controlled or affiliated directly or indirectly with medium

Cite this as:

Pudjiastuti, A. Q., Iriani, N. I., Sa'diyah, A. A. (2018). Sensitivity Analysis of Banana Chips Small Business. Cakrawala, 12(2). 137144. https://doi.org/10.32781/cakrawala.v12i2.2580.

$\begin{array}{ll} & \\ \text { Corresponding author : } & \\ \text { Address } & \text { : Jl. Telaga Warna, Tlogomas, Kec. Lowokwaru, } \\ & \text { Kota Malang, Jawa Timur 65144 } \\ \text { Email } & : \text { agnespudjiastuti@yahoo.com } \\ \text { Phone } & : 081555761529\end{array}$

(C) 2018 Badan Penelitian dan Pengembangan Provinsi Jawa Timur p-ISSN 1978-0354 | e-ISSN 2622-013X 
or large-scale business; e) in the form of an individual business, a non-legal entity, or a legal entity, including a cooperative. This small business criterion is improved through Law No. 20 on 2008, where small businesses own assets $>50-500$ million IDR and turnover $>300$ million -2.5 billion IDR.

Micro-enterprises are part of small businesses that have no less important role in Indonesian economy. According to the Law No. 20 on 2008, micro business is a business activity that can expand employment and provide broad economic services to community and can play a role in process of equity and increase people's income, encourage economic growth, and play a role in realizing national stability. In addition, micro-enterprises are one of a main pillars of national economy that have greatest opportunity, support, protection and broad development as formation of a firm party to people's economic enterprise, without having to ignore the role of large enterprises and governmentowned enterprises. According to Ministry of Manpower, micro business is a business with less than 5 workers.

Small business in Indonesia has been proven to show its existence as a tough economic actor during economic crisis. Some of supporting characteris-tics are that small businesses have no external debt and use local inputs of almost one hundred percent (Swastika, 2014). The contribution of small-scale enterprises to economic growth is also relatively large. In 2012, small businesses in Indonesia, amounted to 56.5 million units (Tambunan, 2013). In Malang district, informal small enterprises grew from 19,453 units in 2010 to 20,430 units in 2014. This small business has been able to absorb labor from 52,815 workers in 2010 to 55,116 workers in 2014 (Dinas Perindustrian, Perdagangan dan Pasar, 2015).
Small business in Indonesia has been proven to show its existence as a tough economic actor during the economic crisis. Some of the supporting characteristics are that small businesses have no external debt and use local inputs of almost one hundred percent (Swastika, 2014). Contribution of small-scale enterprises to economic growth is also relatively large. In 2012, small businesses in Indonesia, amounted to 56.5 million units (Tambunan, 2013). In Malang district, informal small enterprises grew from 19,453 units in 2010 to 20,430 units in 2014. This small business has been able to absorb labor from 52,815 workers in 2010 to 55,116 workers in 2014

Sustainability of banana chips business requires a feasibility study. This analysis is necessary for business owners to have a clear direction on investment plan for their business development, identify possible risks, to provide accurate information in accordance with existing conditions, for decision making and to attract investors.

This studied will be developed by investment of banana chopper technology -from manual to mechanic- so that production capacity will increase. This investment will increase other costs of purchasing raw materials (bananas), additives (salt and sugar), fuel, cooking oil, storage, plastic packaging, and others. Entrepreneur had fluctuation availability of raw materials, price, and demand of banana chips.

Purpose of this study were to analyze profit, break-even, feasibility and responsiveness of banana chips business towards banana price increases and increased costs through additional investment (sensitivity analysis).

\section{Methodology \\ Research Location}

This study was conducted in Jabung Village Pakis District of Malang Regency. Location 
is purposively determined because there are banana chips business in this village that can compete with similar products (cheaper price and better taste than its competitors). Small-scale traditional food business is getting help of banana chopper machine, banana chips storage with large capacity and thicker plastic packaging.

\section{Method of Collecting Data}

Data of feasibility analysis were collected from banana chips business (traditional food business using agricultural commodities as raw material). Primary data was obtained through interviews with employers using structured guidelines. Data collected includes the amount of initial investment in purchase of equipment used in production process of banana chopper machine, frying pan, banana chopped storage, stove, mixing banana chips with auxiliary materials (salt and sugar), storage of banana chips to be packed, scales and seals. Operational costs covered in this study are cost of purchasing raw materials (bananas), auxiliaries (salt and sugar), cooking oil, plastics banana chips, labels and transportation costs. Other data collection methods used was observation during production process.

\section{Data Analysis}

Primary data that have been collected were analyzed using quantitative descriptive analysis method. The analysis of profit and breakeven of banana chips using Soekartawi (2002) as follows.

$$
\begin{aligned}
& \pi=\mathrm{TR}-\mathrm{TC} \ldots \ldots \ldots \ldots \ldots \ldots \\
& \pi=(\mathrm{Q} . \mathrm{Pq})-\mathrm{TC} \ldots \ldots \ldots \ldots \\
& \mathrm{TC}=\mathrm{TFC}+\mathrm{TVC} \ldots \ldots \ldots \\
& \mathrm{BEP}(\text { production})=\mathrm{TC} / \mathrm{P} \\
& \mathrm{BEP}(\text { price })=\mathrm{TC} / \mathrm{Y} . . . \ldots \ldots
\end{aligned}
$$

where $\pi$ is a business profit, Q is a quantity (output), TR is a total revenue, TC is a total cost, TVC is a total variable cost, TFC is a total fixed cost
The feasibility analysis of banana chips business financially using the investment criteria that is NPV, Gross B/C, net B/C and IRR (Ibrahim, 2009; Kasmir, 2003).

$N P V=\sum_{i=0}^{t=n} \frac{B t-C t}{(1+i)^{t}}$

Gross B/C (Gross Benefit-Cost Ratio), the formulation according to Soetriono (2006): Gross $B / C=\frac{\sum P V(B)}{\sum P V(C)}$

$I R R=i_{1}+\frac{N P V_{1}}{N P V_{1}-N P V_{2}} x\left(i_{2}-i_{1}\right)$

Sensitivity analyzes were conducted based on a total cost increase of 5\% (as a result of investment in banana chopper machines and storage boxes) and a 15\% decrease in production (due to limited of raw material supply).

\section{Results and Discussions \\ Characteristics of Enterprises}

Raw material that used was raja nangka banana. The bananas are less favored by consumers because it tastes less delicious to eat directly. But raja nangka is well used as raw material for processed foods because according to Yani et al. (2013), this banana has qualified characteristics in color, texture and flour aspect. Price of the banana as raw material is relatively cheap, so it is more profitable. If raja nangka is not available, the substitute is candi banana, but price of candi is more expensive. Use of more expensive raw materials with assumption of constant output price, will reduce business profits, especially if employers want to increase production capacity.

Banana chips produced by the entrepreneur is superior compared to similar products in local market. Production process starts a selection of raw materials, manufacture until frying is controlled by entrepreneur, so that produced banana chips 
with a consistent taste quality. Banana chips business have had a brand "sopo nyono" and registered number 2143507011839-20.

This banana chips have three variants: sweet banana chips (sugar), sweet taste (Java sugar) and saltiness of onions. Current production capacity reaches 30 $\mathrm{kg}$ per production process with price IDR $35.000,-/ \mathrm{kg}$. Ingredient composition in production process includes 5 bunches of bananas (about $100 \mathrm{~kg}$ of half-ripe bananas), 5 packs of fine salt, $10 \mathrm{~kg}$ of sugar, 200 teaspoons of whiting water, 15 liters of cooking oil. Equipment used during production process was very simple: knives (manual banana chopper) and cutting board, basin or bucket, frying pan, stove, and scales.

Banana chips produced in a single production process of $30 \mathrm{~kg}$, will be sold out for two weeks. Thus, every month was done 2 times the production process so that will be produced $60 \mathrm{~kg}$ banana chips, and raw materials required 10 bunches of bananas, 10 pack of fine salt, $20 \mathrm{~kg}$ sugar, 400 tsp betel water, 30 liters of cooking oil.

\section{Fixed Cost}

Fixed cost of banana chips business was depreciation cost of equipment. Equipment that used in this business was relatively simple. Capital becomes a main obstacle for this business, such as micro business and small business in general. Investment on equipment (gas burner, frying pan, strainer, spatula, banana chopper machine and sealer) as initial investment was is IDR 4.750.000. Depreciation of investment (fixed cost) was IDR 307.000, - per year.

\section{Variable Cost}

Variable costs of banana chips production include cost of purchasing raw materials of Raja Nangka banana, and auxiliary materials such as sugar, cooking oil, and salt, and labor wages. Variable costs in this business (Table 1) were IDR 14,190,000 per year.

\section{Profitability}

Cost, income and profits of banana chips business during 2017 are presented in Table 2 . The calculation show that it profit was IDR 10,703,000. Profit can be greater than this calculation because the production of festivities is assumed to be same as regular day production. According to entrepreneur, demand for banana chips can rise up to 4 times on holidays.

Gross $\mathrm{B} / \mathrm{C}=1.74$, has implication that cost of IDR 1,000,000 banana chips business will generate revenue of IDR 1,740,000. $\mathrm{R} / \mathrm{C}>1$ indicates that the business was feasible. Similar meaning is shown by net $\mathrm{B} / \mathrm{C}$ of 0.74 which implies that for every IDR $1,000,000$ invested in a banana chip business will result in a profit of IDR. 740.000,-. The higher of investment, the greater of revenue and profit, ceteris paribus.

Table 1. Variable Cost of Banana Chips, 2017

\begin{tabular}{|c|c|c|c|c|}
\hline No & Variable (unit) & Price (IDR/ unit) & Quantity & Value (IDR) \\
\hline (1) & (2) & (3) & (4) & $(5)=(3) \times(4)$ \\
\hline 1. & Banana (bunches) & 35000 & 120 & 4.200 .000 \\
\hline 2. & Salt (pak) & 5000 & 120 & 600.000 \\
\hline 3. & Sugar (kg) & 12500 & 240 & 3.000 .000 \\
\hline 4. & Cooking Oil (litre) & 11000 & 360 & 3.930 .000 \\
\hline 5. & Betel water (unit) & 5000 & 12 & 60.000 \\
\hline 5. & Labor (HOK) & 20000 & 120 & 2.400 .000 \\
\hline Total & & & & 14.190 .000 \\
\hline
\end{tabular}

Source: Primary Data, 2017 
Table 2. Cost and Profitability of Banana Chips Production, 2017

\begin{tabular}{|l|l|l|}
\hline No & Description & Value (IDR) \\
\hline 1. & Cost & \\
& Fixed Cost & 307.000 \\
& Variable Cost & 14.190 .000 \\
& Total Cost (a - b) & 14.497 .000 \\
\hline 2. & Total Revenue (quantity x price) & \\
& $720 \mathrm{~kg} \mathrm{x} \mathrm{IDR} \mathrm{35.000}$ & 25.200 .000 \\
\hline 3. & Profit (2-1c) & 10.703 .000 \\
\hline 4. & Gross B/C (2:1c) & 1,74 \\
\hline 5. & Net B/C (3:1c) & 0.74 \\
\hline
\end{tabular}

Source: Primary Data, 2017

\section{Break-Even Point Analysis}

Break-even point (BEP) is an analytical tool used to determine a limit value of production or production volume of a business to break even, or no profit and no loss. Banana chips business was feasible if current production volume greater than $\mathrm{BEP}$ production and price of banana chips currently higher than BEP prices. BEP production and BEP price calculations were presented below.

$$
\begin{aligned}
& \mathrm{BEP}(\text { production })=\frac{\mathrm{TC}}{\mathrm{p}}=\frac{14.497 .000}{35000}=414,2 \mathrm{~kg} \\
& \mathrm{BEP}(\text { price })=\frac{\mathrm{TC}}{\mathrm{Y}}=\frac{14.497 .000}{720}=\text { IDR. } 20.134 / \mathrm{kg}
\end{aligned}
$$

Banana chips business will breakeven if producing banana chips $414,2 \mathrm{~kg}$ per year and if sold at IDR 20.134, - per $\mathrm{kg}$. If compared with current production of banana chips at $720 \mathrm{~kg}$ per year and price received by entrepreneurs is IDR 35,000 per $\mathrm{kg}$, the business was said to be feasible.

\section{Feasibility and Sensitivity Analysis}

In addition to gross $\mathrm{B} / \mathrm{C}$ and net $\mathrm{B} / \mathrm{C}$, other important criteria for assessing business feasibility are NPV and IRR. Changes in costs due to investments in banana chopper machine and storage boxes were IDR $7,000,000$.- (total cost increased by $5 \%$ ) and production down $15 \%$ as raw materials are not available, will be used as a basis for sensitivity analysis. Banana chip business would be feasible if NPV $>0$ and IRR $>i$ (interest rate).

Based on data in Table 3, assuming an interest rate of $17 \%$, it can be seen that NPV $>0$. Furthermore, it can be calculated the amount of IRR is $37 \%$. Formula to calculate IRR was:

$$
\begin{aligned}
& I R R=i_{1}+\frac{N P V_{1}}{N P V_{1}-N P V_{2}} x\left(i_{2}-i_{1}\right) \\
& I R R=17 \%+\frac{10725.17}{10725.17-(-1530.04)} x(40 \%-17 \%) \\
& I R R=37 \%
\end{aligned}
$$

NPV was positive and IRR was greater than interest rate $(17 \%)$ indicates that the business is feasible.

Sensitivity analysis of investment in banana chopper machine, large capacity banana chips storage and plastic packaging quality improvement, which increase total cost by 5\%. Banana chopper machine is necessary to be introduced in banana chip business because entrepreneur still used manual chopper knife as a slicer of banana. According to Wani et al. (2017), the optimum conditions for fried banana chips were obtained at a temperature of $160^{\circ} \mathrm{C}$, time $2.69 \mathrm{~min}$ and slice thickness 
Table 4. NPV at Normal Condition

\begin{tabular}{|c|c|c|c|c|c|}
\hline \multirow{2}{*}{ Year } & \multicolumn{2}{|c|}{ Discount factors } & \multicolumn{3}{|c|}{ NPV at initial condition (IDR. 000) } \\
\cline { 2 - 6 } & $17 \%$ & $40 \%$ & Cash flow & NPV $17 \%$ & NPV $40 \%$ \\
\cline { 2 - 6 } & 1 & 2 & 3 & $(4)=(1) *(3)$ & $(5)=(2) *(3)$ \\
\hline 1 & 0.855 & 0.714 & -7250 & -6198.75 & -5176.5 \\
\hline 2 & 0.731 & 0.510 & -4098 & -2995.64 & -2089.98 \\
\hline 3 & 0.624 & 0.364 & -498 & -310.752 & -181.272 \\
\hline 4 & 0.534 & 0.260 & -498 & -265.932 & -129.48 \\
\hline 5 & 0.456 & 0.186 & 10703 & 4880.568 & 1990.758 \\
\hline 6 & 0.390 & 0.133 & 10703 & 4174.17 & 1423.499 \\
\hline 7 & 0.333 & 0.095 & 10703 & 3564.099 & 1016.785 \\
\hline 8 & 0.285 & 0.068 & 10703 & 3050.355 & 727.804 \\
\hline 9 & 0.243 & 0.048 & 10703 & 2600.829 & 513.744 \\
\hline 10 & 0.208 & 0.035 & 10703 & 2226.224 & 374.605 \\
\hline & & & & 10725.17 & -1530.04 \\
\hline
\end{tabular}

Source: Primary Data, 2017

of $1.5 \mathrm{~mm}$. Therefore, quality banana chips could be developed using theses optimum conditions.

If total cost increase $5 \%$ is still profitable for banana chips business because NPV $>0$ and IRR $=34 \%$ was higher than interest rate $(17 \%)$. Production decreased by $15 \%$ was also still profitable because $\mathrm{NPV}>0$ and IRR $=19 \%$ was higher than interest rate. If total cost increase more than $5 \%$ and a production decline more than $15 \%$ will not profitable for it business.

There are several things that should be done by entrepreneur to keep his business running ie expand the marketing network in order to receive a better price. The facts show that price of banana chips is still lower than its competitors. In addition, better cooperation with raw material suppliers should be further improved. Affandi and Astuti (2014) found that agroindustry development strategy banana chips were utilizing fabric of cooperation with other parties in the application of science and technology in order to produce quality products, banana chips, giving a sense of innovation so that the amount of consumer interest and increasing the demand, and optimization of infrastructure and facilities were owned agro-industries effective and efficient. Pudjiastuti et al. (2016) found that marketing and buyers were dominant factor determining competitiveness of tempeh small businesses.

\section{Conclusions}

Small business of banana chips is a business that generates profits of IDR 10,703,000 per year. The banana chips business will break even if producing $414.2 \mathrm{~kg}$ banana chips per year and if sold at IDR 20,134, - per kg. Based on Gross B/C, NPV and IRR criteria, this small business is feasible. Sensitivity analysis indicates that the total cost increased by 5\% and the production decreased by $15 \%$, still yields positive NPV and IRR higher than the interest rate, so the banana chip business is still feasible. Business owners of banana chips need to expand their marketing network in order to increase sales and better prices. Good relationship with raw material suppliers should be increased, as well as the number of raw material suppliers to ensure the availability of raw materials can be sustainable. 


\section{Acknowledgements}

Thank you very much for the Directorate of Research and Community Service that has funded this activity, as well as to the Rector of Tribhuwana Tungga Dewi University who has provided the facilitation and our partners for their well-cooperation.

\section{References}

Adeyanju, J.A., Olajide, J.O., and Adedeji, A.A. (2016). Optimisation of Deep-Fat Frying of Plantain Chips (Ipekere) using Response Surface Methodology. Journal of Food \& Technology. 7:5. http://dx.doi. org/10.4172/2157-7110.1000584.

Affandi, M.I. dan Astuti, S. (2014). Analysis of Inventory Control and Banana Chips Agroindustry Development Strategy in Bandar Lampung. Agroindustrial Journal 3(2)164-173.

Alex, A., Jeremia, M., George, T. and Anna, S. (2015). Assessment of innovative market access options for banana value chain in Uganda. Journal of Development and Agricultural Economics. Vol. 7(10), pp. 323-331, October, 2015. DOI: $\quad$ 10.5897/JDAE2015.0644. ISSN 2006-9774

Dinas Perindustrian, Perdagangan dan Pasar. (2015). Review Rencana Strategis Satuan Kerja Perangkat Daerah (RENSTRA-SKPD) Kabupaten Malang 2011-2015.

Ibrahim, Y. (2009). Studi Kelayakan Bisnis. Rineka Cipta. Jakarta.

Kasmir, J. (2003). Studi Kelayakan Bisnis. Prenada Media. Jakarta.
Oi, R.K.; Santanac, J.C.C.; Tambourgi, E.B.; Júnior, M. (2013). Feasibility Study for Production of Green Banana Flour in a Spray Dryer. Chemmical Engineering Transactions Vol 32, 2013. ISSN 1974-9791. DOI: 10.3303/CET1332305.

Pudjiastuti, A.Q., Nurhajati, Hardianto, W.T. and Pandulu, G.D. (2016). Determinants of Small Business Competitiveness in Indonesia: Studies in Centre of Tempeh Industry in Malang City. Advances in Environmental Biology. 10(9) September 2016, Pages: 186-193

Soetriono. (2006). Daya Saing Pertanian dalam Tinjauan Analisis. Bayumedia. Malang.

Soekartawi, (2002). Analisis Usahatani. UI Pers. Jakarta.

Sonawane, S.P.; Sharma, G.P. and Pandya, A.C. (2011). Design and development of power operated banana slicer for small scale food processing industries. Res. Agr. Eng.Vol. 57, 2011, No. 4: 144-152.

Swastika, D.L.T. (2014). Klaster UKM. Makalah disampaikan pada Lokakarya Teknologi Untuk Pengembangan Usaha Kecil dan Menengah di Kota Malang, Tahun Anggaran 2014: Optimalisasi Penggunaan Tek-nologi dan Sinkronisasi Kebijak-an untuk Penguatan Teknologi UKM di Kota Malang. Badan Perencanaan Pembangunan Daerah Pemerin-tah Kota Malang.

Tambunan, T. (2013). Reformasi Subsidi Bahan Bakar Fosim dan Usaha Kecil Menengah (UKM): Dampak dan Alternatif Tanggapan. 
Pusat Studi Industri, UKM dan Persaingan Bisnis, USAKTI. Briefing note. Global Subsidies Initiative. Interna-tional Institute for Sustainable Development.

Undang-undang Nomor 9 Tahun 1995 tentang Usaha Kecil.

Wani, S. A., Sharma, V. and Kumar, P. (2017). Effect of processing parameters on quality attributes of fried banana chips. International Food Research Journal 24(4): 1407-1413 (August 2017). Journal homepage: http://www.ifrj.upm. edu.my.

Yani, A.; Arief, R.W.; dan Mulyanti, N. (2013). Processing of Banana Flour Using a Local Banana as Raw Materials in Lampung. International Journal on Advanced Science Engineering Information Technology Vol 3 (2013) No.4. ISSN 2088-5334. 